\title{
SKETSA ARKEOLOGI ISLAM DI MALUKU: Tema dan Implementasi Penelitian ${ }^{1}$
}

\section{The Image of Archaeology of Islam in the Moluccas: Research Theme and Implementation}

\author{
Wuri Handoko \\ Balai Arkeologi Ambon \\ Jl. Namalatu-Latuhalat, Nusaniwe, Ambon-97118 \\ wurhand@yahoo.co.id
}

\begin{abstract}
Abstrak
Penelitian arkeologi Islam di Maluku, merupakan ranah penelitian yang memiliki beragam lingkup dan cakupan kajiannya, karena memiliki dimensi yang luas, antara lain sosial, ekonomi, politik, selain tentu saja religi dan ideologi. Namun luasnya cakupan dalam perspektif horizontal, belum diimbangi oleh penggarapan penelitian yang mendalam (vertikal), sehingga penelitian arkeologi Islam, masih merupakan kepingan atau serpihanserpihan dalam sebuah mozaik hasil penelitian. Implementasi penelitian yang sudah berjalan, baru terbatas menggarap isu-isu pada tataran permukaan, sehingga berbagai hasil kesimpulan tentang peradaban Islam di Maluku., sementara ini baru menampilkan perwajahan Islam yang general. Interpretasi dan kesimpulan yang selama ini dihasilkan, lebih banyak bersandar oleh dukungan data dari lintas batas disiplin ilmu, yang bagaimanapun merupakan kekuatan dari pendekatan arkeologi sejarah. Dari penelitian arkeologi Islam yang sudah dilakukan, pendekatan lintas displin ilmu yakni sejarah dan etnografi, merupakan yang paling umum dilakukan, sementara pendekatan arkeologi sendiri sifatnya masih sangat deskriptif dan belum digunakannya perangkat keras arkeologi, misalnya memanfaatkan data eksavasi dan dating absolute untuk memastikan kapan masyarakat mengkonversi Islam di Maluku. Dalam kurun beberapa tahun, meskipun masih berupa serpihan, namun tampak upaya penelitian arkelogi Islam untuk menjangkau banyak dimensi dari data arkeologi Islam, misalnya yang berhubungan dengan tema Islamisasi dan perdagangan, ekspansi Islam dalam konteks politik dan kultural serta dinamika relasional Islam dan budaya lokal Maluku, serta perkembangan internal Islam itu sendiri dari awal hadirnya hingga persentuhannya dengan kolonialisme.
\end{abstract}

Kata Kunci : Implementasi, Arkeologi, Islam, Data, Maluku

\begin{abstract}
Islamic archaeological research in Maluku, is the realm of research that have diverse scope and coverage of studies, because it has large dimensions, including social, economic, political, besides of course, religion and ideology. However, the wide scope of the horizontal perspective, has not been matched by the cultivation of deep research (vertical), so the archaeological study of Islam, is still a piece or pieces in a mosaic of research results. Implementation research is already running, a new limited work on issues at the level of the surface, so that the various results of conclusions about the Islamic civilization in the Moluccas, while this new show the general appearance of Islam. Interpretations and conclusions that have been produced, more lean by data from cross-border support disciplines, which, however, is the strength of the approach of historical archeology. Of Islamic archaeological research that has been done, crossdisciplinary approach to the science of history and ethnography, the most common, while the archaeological approach itself is very descriptive in nature and has not been used hardware archeology, for example, utilize eksavation data and absolute dating community
\end{abstract}

1 Naskah awal tulisan ini pernah disampaikan dalam Evaluasi Hasil Penelitian Arkeologi (EHPA) yang diselenggarakan oleh Pusat Penelitian dan Pengembangan Arkeologi Nasional pada September 2012 di Solo. 
to ensure that when converting Islam in Maluku. Within a few years, though still in pieces, but it looks Islamic archaeological research efforts to reach out to many dimensions of Islamic archaeological data, such as those related to the theme of Islamization and trade, the expansion of Islam in the political and cultural context and relational dynamics of Islam and local culture of Maluku, as well as internal development of Islam itself from the beginning to the presence touch with colonialism.

Keywords : Implementation, Archeology, Islamic, Data, Maluku

\section{PENDAHULUAN}

Penelitian arkeologi, yang bertumpu pada budaya kebendaan, membantu kita menemukan informasi dari berbagai peninggalan budaya masa lampau baik yang berbentuk artefaktual, maupun fiturfitur bangunan monumental yang masih bisa kita saksikan saat ini, serta berbagai makna simbolik di balik benda budaya itu Dalam konteks ini, termasuk dalam kategori pendekatan arkeologi sejarah (historical archaeology), termasuk di dalamnya Arkeologi Islam (Islamic Archaeology) yaitu arkeologi yang mempelajari masyarakat Islam masa lampau melalui artefak, fitur dan ekofak yang dihasilkan dari masyarakat masa lampau pada masa sejarah, yakni masa ketika sudah mengenal tulisan (Tjandrasasmitha, 2009:109). Azyumardi Azra (2009) mengatakan arkeologi merupakan sala satu ilmu yang sangat dekat bahkan lengket dengan sejarah, karena tujuannya sama yakni mengungkap kehidupan manusia pada masa lalu. Perbedaan keduanya lebih banyak pada penggunaan sumber, sejarah lebih banyak bersandar pada sumber tertulis, sedangkan arkeologi pada sumber berupa benda atau artefak yang antara lain melalui ekskavasi. Lebih lanjut dikatakannya, kajian sejarah Islam sebelum abad ke $15 \mathrm{M}$, sangat memerlukan dukungan bukti-bukti arkeologis. Sejarah masuk dan berkembangnya Islam di Indonesia, katakanlah abad 13-15 M, masih menyisakan banyak pertanyaan yang memerlukan jawaban atas dasar berbaga bukti, khususnya arkeologi. Oleh karena itu, penggunaan data dan bukti arkeologi untuk pengungkapan sejarah Islam Indonesia, menjadi sangat penting.

Dalam proses pencarian dan

pengumpulan data, diperlukan pengetahua atau sekurang-kurangnya mengerti apa yang disebut arkeologi dan atau sejarah (Tjandrasasmitha, $2009: 110$ ).

Tjandrasasmitha, selanjutnya menjelaskan Tjandrasasmitha, selanjutnya menjelaskan
meskipun arkeologi maupun sejarah, terdapat sedikit perbedaan definisi. Arkeologi dalam studinya lebih menitikberatkan kepada benda-benda atau artefak yang tidak perlu ada tulisan, sedangkan sejarah dalam studinya lebih mengutamakan data-data tertulis (arsip, dokumen). Tetapi keduanya baik arkeologi maupun sejarah tujuannya sama yakni untuk merekonstruksi kehidupan masyarakat masa lampau. Sumber tinggalan arkeologis, dapat berupa artefak maupun fitur yang keduanya dapat mengandung tulisan dan ada pula yang tidak. Benda atau bangunan dari masa sejarah yang tidak mengandung tulisanpun, tetapi masuk dalam kategori arkeologi sejarah dalam mencari dan mengkajinya dapat menggunakan data tekstual seperti arsip, dokumen-dokumen, naskah-naskah kuno tentang hikayat, babad, bahkan dongeng ataupun legenda karena mengandung kebenaran atau kenyataan $(\mathrm{H}$.J de Graaf, 1956:55-73; Tjandrasasmitha, 2009:110).

Dalam berbagai literatur sejarah Maluku, kita akan banyak menemukan informasi menyangkut agenda Islamisasi, yang terus bertumbuh dan semakin mapan dengan berdirinya kerajaan-kerajaan Islam di wilayah Maluku Utara. Meskipun dalam porsi yang lebih kecil, kita juga perlu memperoleh dan menemukan catatan sejarah tentang kegiatan penyebaran agama Islam ke wilayah-wilayah lainnya. Tapi sangat sedikit, bahkan mungkin belum ada, tulisan yang secara khusus memberikan informasi perihal keagamaan Islam berlangsung di wilayahwilayah penyebarannya. Kita belum dapat memastikan bagaimana Islam berlangsung di wilayah penyebarannya, mengingat catatan sejarah yang ada, hampir-hampir tak menyentuh wilayah lain di luar empat kerajaan besar Islam di Maluku Utara.

Fakta bahwa wilayah-wilayah seberang dengan ruang geogafis dan sosial yang kecil, namun turut menopang tumbuh dan berkembangnya eksistensi Islam di wilayah Maluku. Dengan fakta yang akan dipaparkan dalam buku ini, kita menjadi tahu bahwa berbicara tentang Islam di wilayah Kepulauan Maluku, bahkan mungkin di seluruh tanah Nusantara ini, kita tidak mungkin hanya cukup berbicara tentang wilayah-wilayah yang besar, namun wilayahwilayah kecil di seberang lautan juga menjadi fakta penting. Justu dari sini kita menjadi paham, bahwa Islam bukanlah agama dan budaya yang hanya berkembang di daerah-derah pusat okupasi atau pusat-pusat peradaban, pusat-pusat kota, pusat-pusat pemerintahan, tetapi juga daerah-daerah terpencil, daerah seberang, daerah pinggiran, dari pesisir hingga pedalaman.

Demikianlah, dalam beberapa tahun ini (setidaknya kurun waktu 5 tahun) penelitian arkelogi Islam di Maluku, masih didominasi penelitian arkeologi di wilayah selatan Kepulauan Maluku, atau yang secara administratif menjadi bagian wilayah Provinsi Maluku.

\section{HASIL DAN PEMBAHASAN}

\section{Arkeologi Islam dan Tema-Tema Penelitian}

Penelitian Arkeologi Islam di Maluku,

dihadapkan pada isu atau masalah penelitian, yang kompleks atau rumit. Hal ini mengingat potensi data yang minim di tengah berbagai konfirmasi sejarah yang saling tumpah tindih dan bersilang pendapat, akibat minimnya tradisi penulisan sejarah di masyarakat Maluku pada umumnya. Selain itu proses sejarah yang berimpitan dan berjarak sangat dekat dengan periode Kolonial, mengakibatkan informasi sejarah tentang Islamisasi, juga berimpitan degan dominasi isu-isu kolonialisme. Tematema penelitian arkeologi Islam, tampaknya tidak bisa berdiri sendiri sebagai satu kajian, melainkan turut bersinggungan dengan kajian arkeologi Kolonial. Mungkin saja, kondis serupa juga demikian adanya pada lokus penelitian arkeologi Islam di luar wilayah Maluku. Namun ekskalasi dan mobilitas kolonialisasi di Maluku yang tinggi, menjadi problem spesifik tersendiri, wilayah kajian Islam di Maluku, yang membedakan dengan wilayah lainnya di Nusantara. Hal in tampaknya yang mengakibatkan dukungan data sejarah tentang Islam di Maluku, tergolong minim.

Sejarah Maluku modern, sesungguhnya puncaknya ditandai sejak berdirinya kesultanan-kesultanan Islam. Informasi sejarah, khususnya tentang sejarah budaya Maluku, tanpa bermaksud menafikkan teks sejarah, tampaknya berbagai informasi sejarah baik yang ditulis dalam teks-teks utuh dalam sebuah buku, maupun berbagai artikel lepas, lebih banyak menyodorkan informas tentang peristiwa-peristiwa yang parsial dan kurang memberi penekanan pada informas dalam konteks dinamika budaya yang lebih uas. Selain itu sejauh ini penulisan sejarah di Maluku, lebih banyak didominasi oleh teksteks sejarah yang umumnya bicara tentang eksistensi kekuasaan Islam, namun dalam lanskap periode kolonial.

Sepanjang yang penulis cermati dari berbagai buku penulisan sejarah, Maluku, pada umumnya masih sangat terbatas dar lingkup wilayah apa yang sekarang disebut sebagai Provinsi Maluku Utara dan itupun didominasi sejarah tentang kolonial (liha Amal 2009 dan 2010; juga Des Alwi, 2005, Jaffar, 2009, dll). Padahal dalam konteks geohistoris, baik wilayah (Provinsi) Maluku Utara, maupun wilayah kepulauan bagian selatannya yakni wilayah yang sekarang menjadi wilayah dari Provinsi Maluku, merupakan satu kesatuan historis. Oleh karena itu memperbincangkan tentang sejarah kepulauan ini, semestinya menjejerkan, mensejajarkan atau menyandingkan wilayah 
Provinsi Maluku Utara dan Provinsi Maluku dalam porsi yang sama. Memang, tak dapat dipungkiri, dalam historiografi lokal, Islam mula-mula berkembang di wilayah yang sekarang disebut sebagai wilayah Maluku Utara, yang berpusat di empat Kerajaan atau kesultanan Islam yang disebut Moluko Kie Raha (Jailolo, Ternate, Tidore, dan Bacan. Sementara itu, penelitian arkeologi Islam sendiri, khususnya di wilayah Maluku Utara juga masih sangat minim, ditambah lagi dukungan data arkeologi Kolonia yang masih dapat kita saksikan juga lebih dominan. Sehingga tampaknya penelitian Utara, masih berupa serp Utara, masih berupa serpihan-serpihan yan publikasinyapun masih dalam skala kecil.

Dari hasil penelitian arkeologi Islam, tampak bahwa penelitian baru mencapa tema-tema general masalah pengaruh Islam, meskipun dari sini kita bisa memperoleh informasi sejarah budaya Islam yang lebih kaya. Sesunguhnya masih banyak pekerjaan rumah untuk mengungkap lebih bayak lag cakupan penjelasan. Dalam hal ini beberapa cakupan penjelasan yang tematis menyangkut perkembangan budaya Islam sebagaiman Wibisono (2009) uraikan sebagai berikut:

a. Perkotaan dan permukiman

b. Teknologi dan craftmenship :

c. Institusional

d. Perniagaan

e. Religi, literasi, dan kesenian:

f. Masyarakat dalam keseharian:

g. Islam dan tradisi:

Dari hasil penelitian yang sudah dilakukan oleh Balai Arkeologi Ambon, secara tematis mungkin baru menguraikan beberapa hal dari tema yang sudah diuraikan diatas antara lain soal perniagaan. Dari paparan evaluasi ini sudah dijelaskan soa perkembangan agenda niaga sepanjang perjalanan pengaruh dan perluasan Islam. Selain itu hasil penelitian juga sudah menghasilkan penjelasan menyangkut budaya Islam dan tradisi, meskipun masih perlu diperluas lagi.
Beberapa tema penting yang perlu dikaji lebih lanjut adalah sebagai berikut :

1. Perkotaan dan pemukiman. Tema ini adalah bagian dari menyajikan dan menjelaskan aspek morphologi kota artinya menelusuri mengapa bentuk kota seperti yang terlihat. Dalam penelitian in tidak hanya aspek arkeologi dan sejarah tetapi juga termasuk rekonstruksi kota dalam konteks lingkungannya, kota disini sebagai tempat tinggal dimana terjadi artikulasi antara penduduk kota (dalam pengertian luas) dengan lingkungan fisiknya, atau dalam mengelola lingkungan. Seberapa jauh perubahan dengn situai aktul jouh perubahan dengan situasi aktual merupakan sat pembahasan. Untuk tema perkotaan dan pemukiman, membutuhkan instrumen data dan metode yang lebih luas, serta membtuhkan waktu yang lebih lama Tentu saja hal ini perlu dipikirkan dari aspek manajemen penelitian, termas aspek m persiapan, pendanaan, dan instrumen penelitian yang dibutuhkan.

2. Dari aspek teknologi, misalnyanya teknologi rancang bangun (arsitektur) masih perlu penelitian dan kajian lebih dalam lagi, tidak hanya menyangkut bangunan peribadatan juga bangunan masa Islam lainnya, apakah istana, rumah tinggal dan sebagainya, serta memperluasan bahasannya mencakup unsur pengaruh antar arsitektur Islam dan pengaruh lokal.

3. Institusional : bagian yang penting adalah melihat pengaruh Islam sebagai bagian dari organisasi sosial dari masyarakat yang kompleks. Pada tataran paling tinggi terdapat sistem birokrasi yang atas nama kerajaan bertindak mewakili institusi dalam hal, seperti kegiata sial, perekonomian untuk pengelolaan dan kelangsungan hidup kerajaan seperti pajak. Sebagian besar dari sub-tema ini di peroleh dari data sejarah, yang adakalanya dapat di dukung data arkeologi, seperti pembagian spatial.

4. Religi, literasi, dan kesenian: dalam puncak pertumbuhan kota permukiman islam memungkinkan berkembangnya literasi yang meliput berbagai aspek apakah sejarah pemerintahan, masyarakat, dan yang tentunya menonjol islamologi terutama berkaitan dengan perkembangan aliaran islam dan penyebarannya. Untuk aspek penelitian ini di wilayah Maluku, masih sebatas melihatnya dalam perbandingan antropologis atau etnografis, melihat tradisi-tradisi Islam yang berlangsung yang mencirikan karakteristik tertentu, sementara dukungan arkeologis masih sangat minim.

Merujuk pembagian tematis penelitian arkeologi Islam seperti yang disebutkan oleh Wibisono (2009), tampaknya beberapa diantaranya memiliki level yang sama, meskipun pada substansinya lebih menitikberatkan pada kajian yang lebih general. Di Balai Arkeologi Ambon, tematema penelitian sejauh ini baru mencakup beberapa tema umum, yakni :

a. Penyebaran, PengaruhdanPerkembangan Islamisasi

Untuk aspek tema ini, wilayah penelitian lebih difokuskan ke wilayahwilayah yang disebut dalam teks sejarah lokal, sebagai wilayah vazal dari Kesultanan Ternate dan Tidore. Perkembangan Islam, juga berhubungan dengan penyebaran Islam dari wilayah pusat peradaban Islam dalam hal ini terutama Ternate dan Tidore ke wilayah Kepulauan Maluku lainnya, terutama di wilayah Maluku Tengah. Perkembangan lanjut, Ternate dan Tidore bersaing memperoleh legitimasi politik sebagai wilayah pusat kekuasaan Islam, sehingga masing-masing kerajaan tersebut bersaing untuk melebarkan sayap kekuasaannya. Ternate berekspansi ke wilayah Seram Barat yakni jazirah Hoamoal, di situ terdapat Kerajaan Hoamoal dan ke wilayah Pulau Ambon, sementara Tidore berkespansi ke wilayah pesisir utara Pulau Seram, Kepulauam
Gorom dan Seram Laut di bagian timur pulau Seram, bahkan mencapai kepulauan Raja Empa, Irian. Peranan Ternate dan Tidore sebagai bandar jalur sutera dengan sendirinya terkait dengan ekspansi itu (Leirizza, 1979) Meskipun kerajaan-kerajaan Islam di wilayah Maluku bagian selatan, budaya masyarakat dengan corak Islam cukup berkembang, namun perkembangannya menjadi daerah Kesultanan seperti halnya di wilayah Maluku Utara tidak terwujud dan ketika pada masa hegemoni kolonial kerajaan-kerajaan in mengalami kemunduran dan kalah dalam peperangan dan politik (Putuhena, 2001:58). Berdasakan hal demikian, penelitian tentang perkembangan Islam diarahkan ke wilayahwilayah yang disebut dalam sejarah lokal sebagai vazal dari kerajaan Ternate dan Tidore. Penelitian yang sudah dilakukan antara lain di wilayah bekas Kerajaan Iha dan Siri Sori Islam di Pulau Saparua, Kerajaan Hatuhaha di Pulau Haruku dan terkahir kerajaan Hoamoal di Pulau Seram. Selain itu juga telah dilakukan penelitian di wilayahwilayah lain yang diantaranya juga daerah perkembangan dari vasal kerajaan-kerajaan Islam itu sendiri. Namun seluruh penelitian yang sudah dilakuakn bisa dikatakan baru pada tahap penjajakan awal, sehingga hasi kajian masih sebatas menelusuri jejak-jejak peradaban Islam di permukaan tanah dan menghimpun data berdasarkan sumber lisan.

Dalam kategori tematis seperti yan disebutkan sebelumnya, mungkin kajian ini merupakan penjabaran dari aspek atau tema berkaitan dengan perkembangan institusional Islam. Kajian ini yang paling umum dan mewarnai hampir setiap usulan penelitian. Namun dukungan data yang minim, dengan pendekatan metodologi yang kurang memadai, baru menghasilkan kajian yang deskriptif. Terutama soal kronologi, belum diperoleh pertanggalan pasti sejak kapan masyarakat mengkonversi Islam. Soal kronologi, sejauh ini baru sebatas mengelaborasi berbagai data sekunder, berupa informasi kesejarahan terutama dengan berdirinya institusi Islam dalam 
hal ini kronologi Islam, lebih di dasarkan pada berdirinya kelembagaan Islam, atau Islam secara resmi menjadi agama kerajaan, yakni pada abad ke $15 \mathrm{M}$. Data artefaktual, diantaranya keramik asing mungkin dapa mengkonfirmasi bagaimana perkembangan Islam di wilayah penelitian, terutama menyangkut aktifitas niaga, mengingat perkembangan Islam, tampaknya suli dilepaskan dari soal perdagangan. Kronologi keramik asing, setidaknya dapat memerikan assumsi atas kronologi perkembangan niaga dan perkembangan Islam itu sendiri, mengingat perdagangan juga melibatkan pedagang-pedagang muslim. Soal kronologi, data yang valid soal pertanggalan masyaraka mengkonversi islam, misialnya hasil dating di Banda Neira oleh Peter Lape (2000) Hasil penelitian menyebutkan kemungkinan masyarakat Banda telah mengkonversi Islam sejak abad $13 \mathrm{M}$, dua abad setengah lebih cepa dari yang discbutkann oleh data sej mengatakan Islamisasi di Banda pada bad 15 $\mathrm{M}$, data ini didukung oleh metodologi tentang pola pemukiman masyarakat masa lampau, berdasarkan data pendukung artefaktual dan ekofak, misalnya tulang binatang, khususnya tulang babi (lihat Lape, 2000). Dari contoh itu, ke depan penelitian arkeologi Islam di Balai Arkeologi Ambon semestinya juga menggunakan dating absolute serta melalui pendekatan metodologi dan data disesuaikan dengan kebutuhan penelitian. untuk lebih memastikan tentang kronolog masyarakat mengkonversi Islam. Hal in sejalan pendapat Azyumardi Azra (2009) yang mengatakan lebih lanjut bahwa kajian sejarah Islam sebelum abad ke $15 \mathrm{M}$, sangat memerlukan dukungan bukti-bukti arkeologis. Sejarah masuk dan berkembangnya Islam di Indonesia, katakanlah abad 13-15 M, masih menyisakan banyak pertanyaan yang memerlukan jawaban atas dasar berbaga bukti, khususnya arkeologi. Oleh karena itu, penggunaan data dan bukti arkeologi untuk pengungkapan sejarah Islam Indonesia, menjadi sangat penting!.

Dari salah satu kajian hasil penelitian, didukung oleh data pustaka, menyangkut kronologi dan perkembangan Islam, hasi penelitian diantaranya disandarkan pula pada tipologi arsitektur masjid, yang dalam beberapa aspek dapat menggambarkan perkembangan Islam, karena pada periode tertentu berkembang bentuk arsitektur yang umum di Nusantara (bahasan ini akan diuraikan lebih lanjut pada subbab berikutnya).

b. Religi Islam dan Dinamika Budaya Lokal

Tema atau isu-isu penelitian menyangkut persentuhan religi Islam dan budaya lokal juga merupakan salah satu isu yang menarik untuk dikembangkan. Studi ini tentu saja melibatkan ilmu-ilmu lain terutama antropologi karena pendekatan data yang digunakan, salah satunya etnograf sebagai data pendukung utama. Tema ini berkaitan dengan tema Islam dan tradisi, dimana di banyak tempat di Nusantara, termasuk di wilayah Maluku, hidup dan masih bertahannya tradisi lokal masyaraka cukup mewarnai dinamika masyarakat dalam menjalankan religi Islam. Masyarakat Maluku yang dikenal kental melanjutkan tradisi, di satu sisi menjadi salah satu peradaban Islam sejak pungkasan abad 15, dengan hadirnya kerajaan-kerajaan Islam. Penelitian arkeologi, masih dipusatkan di wilayah-wilayah yang selama ini dianggap sebagai wilayah sayap perluasan kekuasaan Islam.

Namun kajian-kajian tentang tema demikian, masih bersifat lokalitas, yakni pada lokus-lokus tertentu di wilayah Kepulauan Maluku, belum dapat menjadi gambaran umum di setiap wilayah. Oleh karenanya perhatian, perluasan dan pengembangan kajian mutlak menjadi penting. Namun banyak pula di beberapa tempat dukungan data akeologi yang minim, diantaranya karena berbagai bentuk transformasi budaya masyarakat kekinian, mengakibatkan penarikan kesimpulan atau analisis sudah sulit dilakukan, meskipun dari tradisi lisan masih ditemukan informasi yang serupa. Oleh karena itu kajian-kajian etnoarkeologi dari studi kasus yang spesifik, diharapkan dapat menjadi bahan penarikan kesimpulan dari menjadi bahan penarikan kesimpula

\section{Hasil Penelitian dalam Konteks Dimens}

\section{Data Arkeologi Islam}

Dari beberapa tema penelitian yang menjadi ranah kajian arkeologi islam di Maluku, sebagaimana yang telah diuraikan diatas, namun fakta di lapangan, kajian menjadi lebih berkembang, berdasarkan 'pembacaan' terhadap data arkeologi yang ditemukan, dengan tentu saja dukungan data sejarah dan etnografi. Dengan demikian beberapa tema yang belum tergarap, berdasarkan pengembangan kajian terhadap perolehan data, tema yang dimaksud, meskipun masih bersifat tinjauan awal, sudah coba dijelaskan.

a. Budaya Islam dan Sinkretisme

Salah satu kajian arkeologi Islam yang dapat diangkat dari hasil penelitian adalah yang berhubungan dengan Islam dan tradisi lokal. Meskipun data arkeologi masih minim, menyodorkan informasi tentang keterkaitan antara religi Islam dan tradisi lokal, namun interpretasi dapat diperluas dengan dukungan data etnografi selama penelitian yang telah berlangsung. Kajian ini tampaknya menjadi isu penelitian yang cukup aktual, mengingat tradisi lokal Maluku yang dikenal kuat. Hadirnya pengaruh Islam, tidak serta merta meningkat budaya lokal yang telah mengakar jauh sebelum Islam hadir di tanah Maluku. Dari gambaran data arkeologi dan etnografi, tampaknya dapat diidentifikasi adanya bentuk-bentuk permanensi lokal. Islam pada beberapa aspek berkesinambungan dengan anasir budaya dari etnis tertentu (permanensi etnologis) yang telah muncul jauh sebelum Islam itu sendiri diterima masyarakat (Ambary, 1991, 1998; Mahmud, 2001).

Di beberapa wilayah ini tradisi Islam, yang kental sebagai kelanjutan dari budaya pra Islam, dianggap masih tumbuh subur dan mewarnai keseharian keberislaman masyarakat Maluku pada umumnya. Identifikasi arkeologi memang masih sulit untuk melacak, kecuali hanya bersumber dari data-data tentang tradisi dan tipologi makam kuno, dengan kuantitas data yang minim. Selebihnya data yang paling mendukung, justrtu dari data etnografi, diantra tradisi-tradisi ritual Islam yang masih berlangsung, peringatan hari-hari besar Islam. Namun ada pula data yang tanpa diduga, menyodorkan informasi tentang pemaknaan konteks ruang, assosiasi bangunan masjid dan bangunan rumah adat baeleo. Dimana dari seg keletakannya,menjadi semacam pesan yang dibuat oleh masyarakat pada masa lalu, bahwa masjid berhadapan dengan baeleo, sebagai simbol bahwa agama tidak bisa dipisahkan dari adat. Masjid sebagai simbol agama dan baileu sebagai simbol adat dibangun dalam konteks ruang yang sama, saling berassosias dan keduanya memiliki makna yang saling mengisi. Bahkan isu yang cukup aktual dalam studi arkeologi-antropologi, yang perlu dikembangkan di masa mendatang adalah soal kontinuitas religi prasejarah yang begitu mengakar dan kemungkinan berpengaruh terhadap munculnya sinkretisme Islam, di wilayah Maluku.

. Proses dan Kronologi Islamisasi : Dimensi Politik dan Kultural

Tema penelitian arkeologi sejarah Islam yang paling general adalah menyangkut perkembangan pengaruh dan penyebaran Islam, sebagaimana yang telah dtuliskan sebelumnya. Namun untuk kasus Maluku, masalah penyebaran Islam, merupakan fenomena yang kompleks, karena proses ekspansi dengan mobilitas tinggi, dan bersangkut paut dengan keterlibatan pihak kolonial. Tampaknya, di wilayah MalukuMaluku Utara soal persaingan dan ekspansi kekuasaan yang seiring dengan agenda Islamisasi, dipertajam lagi oleh kekuatan hegemoni Kolonial sangat mempengaruh tumbuh dan berkembangnya budaya Islam, sekaligus menjadi pemicu atas faktor perbedaan karakteristik budaya Islam yang berlangsung. Mungkin tidak ada hubungan 
sebab akibat atau kausalitas antara agenda ekspansi kekuasaan Islam, dengan corak Islam yang dilahirkan oleh karena Islamisas Islam yang dilahirkan oleh karena Islamisasi
berjalan seiring dengan agenda kekuasaan berjalan seiring dengan agenda kekuasaan
dan politik. Namun, ada hal-hal yang menjadi petunjuk, bahwa wilayah-wilayah seberang, secara kebetulan menunjukkan corak atau karakteristik Islam yang dipengaruhi oleh perkembangan Islam dibawah pusat oleh perkembangan Islam dibaw
kekuasaan Islam Maluku Utara.

Islamisasi di wilayah Maluku, tidak bisa dilepaskan dari sejarah Islamisasi di wilayah Maluku Utara. Banyak penulisan sejarah Maluku berisi pula berbagai penjelasan menyangkut sejarah penyebaran Islam di wilayah ini. Banyak kajian menjelaskan tentang sejarah islamisasi $\mathrm{d}$ wilayah Maluku meliputi, proses penyebaran Islam, negara penyebar, proses penerimaan hingga perkembangannya. Meski demikian, hingga saat ini, teori tentang jalur Islamisasi di Kepulauan Maluku (Provinsi Maluku dan Maluku Utara) masih terus dalam proses kajian. Beberapa pendapat yang mengemukakan teori masuknya Islam di wilayah ini diantaranya oleh Mailoa (1977), bahwa Islam berkembang di Maluku Utara diduga berasal dari Malaka, Kalimantan, atau Jawa. Prodjokusumo (1991), mengemukakan bahwa Banjar dan Giri atau Gresik cukup besar pengaruhnya dalam sosialisasi Islam di Maluku Utara, sebelum terjadi arus balik, yakni penyebaran Islam dari Maluku ke arah barat yakni Buton dan daerah lain di Sulawesi Selatan (Mailoa do dalam Ambary; 1998:153). Meski demikian, penting dicatat, Islam dianggap masuk ke wilayah Maluku pada sekitar abad 14, seperti yang terkandung dalam tradisi lisan yang menyebutkan Raja Ternate XII akrab dengan pedagang Islam (Ambary, 1996:6) Berdasarkan hal tersebut Ambary (1998) mengemukakan kemungkinan lain bahwa Islam masuk melalui jalan Cina Selatan dan tidak melalui Selat Malaka. Pada abad 15, Ternate merupakan pusat kekuatan utama penghasil rempah-rempah. Diantar kerajaan besar lainnya, seperti Tidore, Jailolo dan Bacan,Ternate menjadi pusat untuk memimpin aliansi empat kerjaan tersebut (Ambary, 1998:153-154).

Tampaknya historiografi Islam di Maluku, mula-mula dikenal setelah munculnya Kerajaan Hitu. Hitu dianggap sebagai Kerajaan Islam terbesar di Provinsi Maluku, berdiri pada posisi strategis di bagian utara Pulau Ambon, yang secara geografis memudahkan penyebaran Islam ke wilayah lainnya yakni ke wilayah Pulau Seram, Haruku dan Saparua. Data yang diperoleh dari penelitian Sahusilawane (1996) masih sebatas mendeksripsikan data koleksi penduduk dan beberapa makam kuno Rajaraja Hitu, dan masih terbatas pada lokas yang kini disebut sebagai Negeri Hitu Lama. Pelacakan bukti-bukti arkeologi dengan jangkauan wilayah yang lebih luas perlu direncakan secara matang, dengan jangkauan penelitian dan pendalaman terhadap data serta pengumpulan, deskrprispi berbagai data baik survei, dan terutama pula ekskavas sangat penting, di samping berbagai bentuk hasil karya literasi baik alquran kuno maupun naskah kuno lainnya juga perlu dikaji lagi.

$$
\text { Kita belum akan memberi kesimpulan }
$$
yang pasti, tentang sejak kapan Islamisasi berlangsung. Fakta yang lebih jelas, baik dari informasi yang dihasilkan oleh data arkeologi maupun sejarah, tampaknya lebih mengarahkan bahwa perkembangan Islam mengalami puncaknya ketika munculnya kerajaan-kerajaan bercorak Islam yang berkembang menjadi daerahdaerah kesultanan sebagai pusat kekuasaan sekaligus peradaban Islam, pada kisaran Abad 15 M. Masih diperlukan berbagai rangkaian penelitian untuk memperoleh sumber atau data-data primer untuk menjawab berbagai pertanyaan penelitian menyangkut Islamisasi, dan berbagai fenomena budaya yang mengikut.

c. Perkembangan Islam dalam Perwajahan Arsitektur Masjid Kuno di Maluku

Aspek teknologi dalam rancang bangun pada masa Islam, tampaknya dapat didentifikasi dari kajian atas arsitektur masjid kuno di Maluku. Mekipun belum diajukannya penelitian khusus untuk mengidentifikasi arsitektur masjid kuno, namun dalam penelitian yang general menyangkut tema penyebaran dan pengaruh Islam, dimensi data monumental masjid kuno, menjadi bagian yang otomatis dijangkau, mengingat di beberapa wilayah penelitian, masih dapat dijumpai masjid kuno yang masih bertahan hingga sekarang. Dari studi kasus kajian masjid kuno di Negeri Rohomoni, Pulau Haruku misalnya, dapat ditarik generalisasi bahwa kemungkinan tipologi dan karakteristik arsitektur masjid kuno di Maluku pada umumnya. Hal ini masih membutuhkan perluasan kajian untuk kasus masjid kuno lainnya di wilayah lokus berbeda. Namun banyaknya masjid kuno, yang kini banyak mengalami perubahan, tampaknya sementara ini tipologi masjid kuno di Pulau Haruku dan Kaitetu Maluku Tengah bisa mewakili secara umum tipologi arsitektur masjid kuno di seluruh wilayah Maluku. Aspek teknologi ini, didalamnya juga terkait berbagai makna simbolik, nilai-nilai budaya yang harus diperluas dan diperdalam lagi kajian dan analisisnya, antara lain soal konsep arsitektur berdasdarkan cara pandang Islam maupun konsep lokal, integrasi nilai budaya Islam dan lokal yang juga telah coba diuraikan dalam perluasan kajian dari penelitian yang sudah dilakukan.

Bicara tentang perkembangan pengaruh Islam, maka tak bisa dilepaskan dengan perkembangan arsitektur masjid, karena masjid merupakan ikon utama perkembangan Islam itu sendiri. Awal mula dan perkembangan rancang bangun masjid, bisa menjadi petunjuk tentang bagaimana proses awal Islamisasi hingga perkembangannya kemudian. Menurut De Graaf dan Pijper, bentuk atap tumpang tiga atau bahkan lima susun dari masjid, mulai muncul di akhir abad $16 \mathrm{M}$, sebuah bentuk yang khas yang disebutnya sebagai superstruktur segitiga atau adapula yang menyebutnya sebagai piramida. Ternyata di Nusantara, atap tumpang pada masjid merupakan contoh arsitektur masjid di banyak tempat di Nusantara sebut saja Aceh, Demak, Banten, Kudus dan Ternate (Kees, 2009:52). Ciri spesifik lainnya adalah adanya 'tiang alif' dipuncak atap tumpang atau atap yang paling atas yang disebut sebagai mustaka atau memolo. De Graaf dan Pijper mengatakan prototipe masjid ditemukan dimana-mana, dari Aceh hingga Ambon. Karakteristiknya sama, yakni yang utama adalah arsitektu atap. Masjid-masjid itu memiliki atap tumpang tiga sampai lima tingkat, makin ke atas makin kecil (Kees, 2009:580).

Dari sekian banyak tulisan menyangkut pengaruh arsitektur masjid kuno di Nusantara pada umumnya bersandar pada kesimpulan bahwa arsitektur masjid kuno, secara tipologis, merujuk pada arsitektur masjid yang banyak dipengaruhi unsur budaya Hindu-Jawa, maupun budaya Jawa. Namun dalam beberapa tipe, terdapat karakteristik yang berbeda, dan untuk wilayah Maluku, memiliki beberapa karakteristik yang khas Maluku dan berbeda dengan wilayah lainnya di Nusantara. Pada dasarnya, arsitektur masjid kuno di Maluku, dapat diidentifikasi untuk menghasilkan kesimpulan tentang bagaiman pengaruh Islam di Maluku, dan dari man pengaruh itu muncul. Dengan demikian, maka pengaruh Islam di Maluku, berdasarkan jejakjejak arkeologi Islam yang ditinggalkan dan masih dapat disaksikan hingga saat ini, dapat memberikan informasi berharga bahwa Islam di Maluku, kemungkinan berasal dari banyak sumber, tidak menutup kemungkinan pusat kekuasaan Ternate dan Tidore, Jawa bahka kemungkinan berhubungan pula dengan sumber langsung dari Arab, Persia maupun India (Gujarat). Yang jelas, baik Arab, Persia, Gujarat (India), China, Sumatra dan Jawa, seluruhnya kemungkinan berjasa sebaga agen-agen penyebaran Islam di Maluku baik melalui perantara niaga maupun dalam praktek-praktek misi penyebaran Islam secara langsung. 
d. Perkembangan Tata Kota Islam : Studi Kasus Kota Ternate

Dalam penelitian mutakhir, telah dilakukan sebuah penelitian awal untuk mengidentifikasi morphologi kota Ternate. Dalam artikel ini, diuraikan secara ringkas beberapa intisari dari kajian tentang tat kota Islam Ternate. Penelitian tentang tata kota adalah salah satu domain penting dalam arkeologi yang selama ini masih dianggap studi yang sangat terbatas. Penelitian in dengan mengambil setting Kota Ternate pada periode Islam hingga Kolonial, merupakan sebuah penelitian awal untuk melihat bentuk dan dinamika kota dernate, adah sebuah kota klasik yau. berkete, adalah sebuah kota klasik yan berkembang pada masa pengaruh Islam, wilayah ini menjadi pusat pemerintaha Islam Kesultanan Ternate. Tipikal kota klasi di Asia Tenggara, salah satu karakteristik menonjol adalah konsepsi kosmologi, yakn harmonisasi antara manusia dalam ruang dan lingkungannya. Sebagai kota kuno Islam, Ternate telah berkembang sejak pengaruh Islam hingga kini. Wajah kota dengan berbagai elemennya menandai sebua kemajuan peradaban yang dibalut ole konsepsi tentang pendirian kota sebagaiman kota Islam lainnya.

Dalam konsep kota Islam, pusat kota dapat disebut sebagai pusat orientasi, biasany dimanifestasikan dengan suatu wilayah yan homogen atau sakral. Dalam hal ini Kot Ternate, dengan pusatnya ditandai oleh kedaton Sultan, sebagai pusat pemerintahan, berikut komponen pengikut lainnya seperti alun-alun dan masjid, selain sebagai pusa pemerintahan, dianggap pula sebagai pusa kebudayaan. Sebagai pusat pemerintahan, dimana raja atau Sultan tinggal, maka kraton dianggap sebagai miniatur dari makrokosmo (Handinoto, 2010:219). Wilayah keraton, bisanya selalu diangeap sebagai suatu yan bisanya se (sakral) yang teratur atau yang homogen (sakral) yang teratur atau harus diatur. Bangunn kedon ke arah Timur atau ke arah laut.

Tema dan kajian penelitian perlu diperluas lagi, hal-hal yang belum dikaj menyangkut tata kota dan pola pemukima dalam masa pengaruh islam, perlu dikaji lebih dalam, terutama di wilayah lokus penelitian yang dalam konteks sejarah merupakan pusat pemerintahan Islam, demikian pula dengan aspek atau tema menyangku teknogi ranceng bangun, sistem birokut den birokrasi dan pemerintahan, serta perkembangan struktur sosial masyarakat dan juga apakah bentuk kota juga bisa menggambarka perkembangan struktur pemerintahan.

\section{PENUTUP}

Secara umum, penelitian arkeolog Islam di Maluku berupaya menjangkau cakupan tematis dalam melihat perkembangan budaya Islam di Maluku. Meski demikian luasnya cakupana tema penelitian arkeolog Islam, baru menjangkau berbagai dimens data arkeologis yang bisa menjelaskan tentang sejarah budaya Islam, dan itupu masih sejar masih bersifat kajian awal dan pendekatan yang general. Banyaknya kategori dat arkeologi yang belum dicapai adalah soalan yang harus dipikirkan sebagai bagian dari upaya pengembangan, perluasan dan pendalaman kajian. Terutama soal kronologi, adalah masalah yang paling penting yang perlu dijelaskan dalam penelitian-penelitian mendatang. Penjelasan kronologi yan relative, terutama bersumber dari data sejarah, dan kalaupun muncul data arkeologi yan ditemukan untuk menjelaskan kronologi, sifatnya relatif dan lebih banyak disandarka pada kronologi Islamisasi pada masa Islam diterima secara rakyat ataura kamama rakyat atau agama kerajaan yang secar resmi diakui dalam struktur sosial da pemerintahan pada masa kerajaan atau tradisi tutur, bahwa Islam telah hadir jauh sebelum yang disebutkan dalam literatu sejarah, inilah yang masih memerlukan pembuktian arkeologis, melalui ekskavasi dan pertanggalan mutlak, selain tentu saja metodologi yang sesuai untuk menjelaskan hal tersebut.

Selain itu dimensi data arkeologi yang penting, yang dapat menjelaskan diimensi pelitik dan kultural islam, juga masih politik dan kultural islam, juga masi yang ak jal, hal ini karalah penelitian yang aktual, hal ini karena menjangkau beberapa cakupan tematis, baik berhubungan dengan struktur pemerintaan dan kekuasaa Islam, ekspansi atau proses perluasan Islam, perkembangan Islam itu sendiri baik secara eksternal maupun internal hingga soal praktek-praktek religi Islam dalam keseharian masyarakat yang dibungkus dengan berbagai tradisi yang masih melekat.

Dalam prakteknya isu-isu strategis penelitian dan tema-tema penelitian yang menarik yang diancangkan untuk mengungkap sejarah budaya masyarakat, di lapangan tidak dapat berjalan optimal. Berbagai kondisi sosial di masyarakat, soal kebiasaan atau tradisi hingga persepsi masyarakat dalam memandang data arkoelogi, menjadi kendala tersendiri bagi peneliti untuk melakukan penelitian. Banyak kasus soal tabu dan hal-hal yang bersifat primordial, terkadang menjadi sandungan tersendiri untuk dapat mendeskripsikan data arkeologi, sehingga analisis dan kajian tidak optimal.

Meski demikian, berbagai data arkeologi, diharapkan menjadi stimulus penting untuk membangun integrasi dan harmonisasi sosial. Berbagai event publikasi, misalnya pameran, penyuluhan dan seminar banyak diapresiasi masyarakat, terutama data arkoelogi yang memberikan pencerahan tentang integrasi sosial dan pemupukan jatidiri atau identitas. Yang justru harus diperhatikan adalah bahwa secara internal, instansi penelitian secara organisatoris dan manajemen, perlu banyak berbenah, agar berbagai target penelitian mencapai hasil optimal, dan hasil penelitian benar-benar mampu diaktualisasikan dalam membangun integrasi kebangsaan, serta memberikan pencerahan tentang identitas kebangsaan, yang lahir dari kemajemukan namun terintegrasi dan saling mengisi di dalamnya.

Dalam pelaksanaan penelitian, perlunya pembinaan terstruktur dan sistematis terhadap para peneliti di wilayah kerja Unit Pelaksana Tugas (UPT) melalui mekanisme monitoring dan evaluasi, agar dapat diamati perkembangan penelitian di daerah, kendala yang dihadapi serta solusisolusi untuk menghasilkan penelitian yang lebih berkualitas.

\section{DAFTAR PUSTAKA}

Alwi, Des, 2005 Sejarah Maluku: Banda Neira, Ternate, Tidore dan Ambon. Jakarta. Dian Rakyat

Amal, Adnan M. 2009, Portugis dan Spanyol di Maluku. Jakarta. Komunitas Bambu.

2010. Kepulauan Rempahrempah Perjalalanan Sejarah Maluku Utara 1250-1950. Jakarta. Kepustakaan Populer Gramedia

Ambary, Hasan Muarif, 1986 Unsur Tradisi Pra Islam Pada Sistem Pemakaman Islam di Indonesia. Pertemuan Ilmiah Arkeologi IV Jakarta. Depdikbud.

1991 Makam-Makam Kesultanan dan Para Wali Penyebar Islam di Pulau Jawa. Aspek-Aspek Arkeologi Indonesia. Pusat Penelitian Artkeologi Nasional. Jakarta

1998 Menemukan Peradaban Arkeologi dan Islam di Indonesia. Jakarta: Pusat Penelitian Arkeologi Nasional. Logos. Wacana Ilmu.Jakarta.

Dijk, Van Kees, 2009 Perubahan Kontur Masjid dalam Peter J.M Nas dan Martien de Vletter (editor) Masa Lalu dalam Masa Kini Arsitektur di Indonesia. Jakarta. Gramedia Pustaka Utama

Handinoto, 2010 Arsitektur dan Kota-Kota d Jawa pada Masa Kolonial. Yogyakarta. Graha Ilmu.

Guillot, C dan H. Chmabert-Loir, 2007 Ziarah dan Wali di Dunia Islam. Jakarta. Komunita Bambu

Lape, P. V. 2000a Contact and Conflict in the Banda Islands, Eastern Indonesia, 11th 17 th Centuries. Ph.D. Dissertasi. Brown University.

Lape, P.V 2000b Political dynamics and religious change in the late pre-colonial Band Archaeolooy 32(

Lapian, Andrian B, 2001. Ternate Sekitar Pertengahan Abad Ke-16. Dalam M.J. 
Abdulrahman, et.al. Ternate: Bandar Jalur Sutera. LInTas (Lembaga Informasi dan Transformasi Sosial). Ternate.

,2010 Wilayah Maluku dalam Konteks Perdagangan Internasional Masa Lampau dan Globalisasi. Makalah dalam Seminar Nasional Sail Banda 2010. Ambon 2 Agustus 2010. Balai Arkeologi Ambon

Leirissa, RZ, 1980 Maluku Tengah dalam Abad Ke-19, Prisma No. 8 Agustus Tahun IX

, 2001. Jalur Sutera: Integrasi Laut-Darat dan Ternate sebagai Bandar di Jalur Sutera. Dalam M.J. Abdulrahman, et.al. Ternate: Bandar Jalur Sutera, Ternate: LinTas (Lembaga Informasi dan Transformasi Sosial)

Mahmud, Irfan 2001 Determinasi Budaya Islami di Wilayah Pinggiran Kekuasaan Bugis. WalannaE. Jurnal Arkeologi Sulawesi Selatan dan Tenggara. Vol IV No 6 Juni. Balai Arkeologi Makassar.

Putuhena, Shaleh 2001 Proses perluasan agama Islam di Maluku Utara. Dalam M.J. Abdulrahman, et.al. Ternate: Bandar Jalur Sutera, Ternate: LinTas (Lembaga Informasi dan Transformasi Sosial). Ricklefs, M.C 2008 Sejarah Indonesia Modern 1200-2004. Jakarta. PT Serambi Ilmu Semesta.

Sahusilawane, 1996 Laporan Hasil Penelitian Arkeologi Islam di Kecamatan Leihitu Kabupaten Maluku Tengah. Ambon. Balai Arkeologi Ambon.

Sutiyono, 2010 Benturan Budaya Islam: Puritan dan Sinkretis. Jakarta. Penerbit Kompas

Spradley, James P, 1997 Metode Etnografi. Terjemahan oleh Misbah Zulfa Elizabeth. PT Tiara Wacana Yogya. Yogyakarta Kediri 23-28 juli 2002. Ikatan Ahli Arkeologi Indonesia

Tjandrasasmitha, Uka 2009 Arkeologi Islam Nusantara. Jakarta. Kepustakaan Populer Gramedia (KPG).
Wibisono, Sonny, 2009 Evaluasi Penelitian Kajian Arkeologi Pengaruh Islam di Nusantara. Evaluasi Hasil Penelitian (EHPA). Denpasar. Bali. Pusat Penelitian dan Pengembangan Arkeologi Nasional 